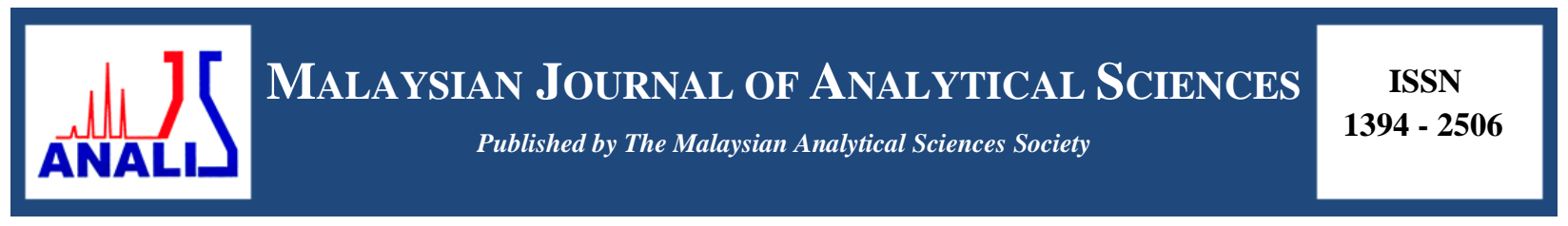

\title{
INFLUENCE OF CHROMIUM ON THE REDUCTION BEHAVIOR OF FERRIC OXIDE BY USING CARBON MONOXIDE: TEMPERATURE PROGRAMMED REDUCTION AND KINETIC STUDIES
}

\author{
(Pengaruh Kromium Terhadap Kelakuan Penurunan Ferik Oksida dengan Menggunakan Karbon \\ Monoksida: Kajian Penurunan Suhu Berprogram dan Kinetik) \\ Tengku Shafazila Tengku Saharuddin ${ }^{1}$, Alinda Samsuri ${ }^{1,2}$, Fairous Salleh ${ }^{1}$, Mohammad Bin Kassim ${ }^{1}$, \\ Rizafizah Othaman ${ }^{1}$, Mohamed Wahab Mohamed Hisham ${ }^{1}$, Mohd Ambar Yarmo ${ }^{1}$ \\ ${ }^{1}$ School of Chemical Science and Food Technology, Faculty of Science and Technology \\ Universiti Kebangsaan Malaysia, 43600 UKM Bangi, Selangor, Malaysia \\ ${ }^{2}$ Centre for Defence Foundation Studies, \\ Universiti Pertahanan Nasional Malaysia, Kem Sungai Besi, 57000 Kuala Lumpur, Malaysia \\ *Corresponding author: tengkushafazila@gmail.com
}

Received: 24 February 2015; Accepted: 27 October 2015

\begin{abstract}
This study was undertaken to investigate the effect of chromium on the reduction behaviour of ferric oxide with carbon monoxide $(10 \%, \mathrm{v} / \mathrm{v})$ in nitrogen as a reductant. Ferric oxide was impregnated with $3 \%$ chromium to produce chromium-doped ferric oxide $\left(\mathrm{Cr}-\mathrm{Fe}_{2} \mathrm{O}_{3}\right)$. The reduction behaviour and the kinetic studies of $\mathrm{Cr}-\mathrm{Fe}_{2} \mathrm{O}_{3}$ and $\mathrm{Fe}_{2} \mathrm{O}_{3}$ have been studied by temperature programmed reduction (TPR) and the phases formed of partially and completely reduced samples were characterized by X-ray diffraction spectroscopy (XRD). Meanwhile, the activation energy values were calculated from the Arrhenius equation using Wimmer's method. TPR results indicate that the reduction of $\mathrm{Cr}-\mathrm{Fe}_{2} \mathrm{O}_{3}$ proceeded in two reduction steps $\left(\mathrm{Fe}_{2} \mathrm{O}_{3} \rightarrow \mathrm{Fe}_{3} \mathrm{O}_{4} \rightarrow \mathrm{Fe}\right)$, while, $\mathrm{Fe}_{2} \mathrm{O}_{3}$ proceeded in three reduction steps $\left(\mathrm{Fe}_{2} \mathrm{O}_{3} \rightarrow \mathrm{Fe}_{3} \mathrm{O}_{4} \rightarrow \mathrm{FeO} \rightarrow \mathrm{Fe}\right)$ with doped ferric oxide showed a large shifted towards lower temperature. The complete reduction of ferric oxide to metallic Fe occur at $700{ }^{\circ} \mathrm{C}$ compared to the undoped ferric oxide $\left(900{ }^{\circ} \mathrm{C}\right)$. The XRD pattern showed that the diffraction peaks of $\mathrm{Cr}-\mathrm{Fe}{ }_{2} \mathrm{O}_{3}$ are more intense compare to $\mathrm{Fe}_{2} \mathrm{O}_{3}$, indicating that the improvement on the crystallinity of the characteristic peaks of $\mathrm{Fe}_{2} \mathrm{O}_{3}$ with no additional peak observed meaning that the chromium particles loaded on the ferric oxide were well dispersed. Furthermore, additional of 3 $\%$ chromium on ferric oxide gives larger surface area and decrease in the activation energy up to $12.39 \%$ regarding to transition phases of $\mathrm{Fe}_{2} \mathrm{O}_{3} \rightarrow \mathrm{Fe}_{3} \mathrm{O}_{4}$ during the reduction process may also led to the increase in the rates of ferric oxide reduction.
\end{abstract}

Keywords: temperature programmed reduction, kinetic, reduction, ferric oxide, chromium, carbon monoxide

\begin{abstract}
Abstrak
Kajian ini dijalankan untuk melihat pengaruh kromium pada kelakuan penurunan ferik oksida di mana karbon monoksida (10\%, $\mathrm{v} / \mathrm{v})$ di dalam nitrogen digunakan sebagai agen penurunan. Serbuk ferik oksida yang didopkan pada kromium $\left(\mathrm{Cr}-\mathrm{Fe}_{2} \mathrm{O}_{3}\right)$ disintesis menggunakan kaedah impregnat. Kelakuan penurunan dan kinetik oleh $\mathrm{Cr}-\mathrm{Fe}_{2} \mathrm{O}_{3}$ and $\mathrm{Fe}_{2} \mathrm{O}_{3}$ dikaji menggunakan teknik suhu penurunan berprogram (TPR) dan fasa - fasa yang terbentuk bagi separa dan penurunan penuh dicirikan menggunakan teknik pembelauan sinar X (XRD) sementara nilai - nilai tenaga pengaktifan dikira daripada persamaan Arrhenius dan kaedah Wimmer. Profil TPR menunjukkan bahawa penurunan ferik oksida yang didopkan kromium melalui dua langkah tindak balas penurunan $\left(\mathrm{Fe}_{2} \mathrm{O}_{3} \rightarrow \mathrm{Fe}_{3} \mathrm{O}_{4} \rightarrow \mathrm{Fe}\right)$ manakala ferik oksida yang tidak didopkan melalui tiga langkah tindak balas penurunan $\left(\mathrm{Fe}_{2} \mathrm{O}_{3} \rightarrow \mathrm{Fe}_{3} \mathrm{O}_{4} \rightarrow \mathrm{FeO} \rightarrow \mathrm{Fe}\right)$. Suhu proses penurunan tamat beranjak kepada suhu yang lebih rendah iaitu $700{ }^{\circ} \mathrm{C}$ dan proses penurunan tamat pada suhu $\left(900{ }^{\circ} \mathrm{C}\right)$. Difraktogram XRD terhadap $\mathrm{Cr}-\mathrm{Fe}_{2} \mathrm{O}_{3}$ menunjukkan peningkatan pada kehabluran puncak $\mathrm{Fe}_{2} \mathrm{O}_{3}$ berbanding ferik oksida yang tidak didopkan dengan tiada puncak tambahan diperhatikan dimana ia
\end{abstract}




\section{Tengku Shafazila et al: INFLUENCE OF CHROMIUM ON THE REDUCTION BEHAVIOR OF FERRIC OXIDE BY USING CARBON MONOXIDE: TEMPERATURE PROGRAMMED REDUCTION AND KINETIC STUDIES}

menjelaskan bahawa zarah kromium yang dimuatkan pada ferik oksida telah tersebar dengan baik. Di samping itu, tambahan sebanyak $3 \%$ kromium pada ferik oksida memberikan kawasan permukaan yang lebih besar dan pengurangan tenaga pengaktifan sehingga $12.39 \%$ bagi peralihan fasa $\mathrm{Fe}_{2} \mathrm{O}_{3} \rightarrow \mathrm{Fe}_{3} \mathrm{O}_{4}$ serta juga membawa kepada peningkatan kepada kadar proses penurunan ferik oksida tersebut.

Kata kunci: penurunan suhu berprogram, kinetik, penurunan, ferik oksida, kromium, karbon monoksida

\section{Introduction}

Reduction of ferric oxide was a subject of numerous studies due to the importance of iron and steel in the current and future technologies [1]. The iron and ferric oxide are nontoxic and cheap materials give them as an important chosen material in the catalysis field [2,3]. As a catalyst, the reduction behaviour and the degree of reduction of the iron species were highly important in such catalysis and previous studies, reaction temperature of ferric oxide reduction was determined using thermodynamics $[4,5]$ and experimental $[1,6]$. The reduction process of $\mathrm{Fe}_{2} \mathrm{O}_{3}$ involves different mechanism depending on temperature, particle size, concentration reduction gas used and additives to the $\mathrm{Fe}_{2} \mathrm{O}_{3}$ [7-9]. Reduction by carbon monoxide generally involves two-steps reduction can be described as equation 1 and 2 follows [7-9]:

$$
\begin{array}{lr}
3 \mathrm{Fe}_{2} \mathrm{O}_{3}+\mathrm{CO} \rightarrow 2 \mathrm{Fe}_{3} \mathrm{O}_{4}+\mathrm{CO}_{2} & \Delta \mathrm{H}_{\mathrm{r}}=-47.2 \mathrm{kJmol}^{-1} \\
\mathrm{Fe}_{3} \mathrm{O}_{4}+4 \mathrm{CO} \rightarrow \mathrm{Fe}+4 \mathrm{CO}_{2} & \Delta \mathrm{H}_{\mathrm{r}}=-13.6 \mathrm{kJmol}^{-1}
\end{array}
$$

Meanwhile three steps reduction is additional of another two subsequent steps from the final process of $\mathrm{Fe}_{3} \mathrm{O}_{4}$ directly reduce to metallic iron (equation 3 and 4 ) as describe below:

$$
\begin{array}{lc}
\mathrm{Fe}_{3} \mathrm{O}_{4}+\mathrm{CO} \rightarrow 3 \mathrm{FeO}+\mathrm{CO}_{2} & \Delta \mathrm{H}=19.4 \mathrm{kJmol}^{-1} \\
\mathrm{FeO}+\mathrm{CO} \rightarrow \mathrm{Fe}+\mathrm{CO}_{2} & \Delta \mathrm{H}=-11.5 \mathrm{kJmol}^{-1}
\end{array}
$$

Briefly, equations (1) and (2) are responsible for the two-step reduction and whereas a sequence of equations (1), (3) and (4) represents the three-step reduction. Furthermore, the thermodynamic calculations based on the Gibbs free energy change due to reaction and the equilibrium composition of the oxides for the equations above indicate that equation (1), (3) and (4) are spontaneous with $\Delta \mathrm{G}$ between -102.3 to $+9.61 \mathrm{kJmol}^{-1}$ at temperature $300{ }^{\circ} \mathrm{C}$ to $900{ }^{\circ} \mathrm{C}$. While, the reduction process for equation (2) is thermodynamically more favourable at rather lower temperatures (below $500{ }^{\circ} \mathrm{C}, \Delta \mathrm{G}<+20 \mathrm{kJmol}^{-1}$ ). In addition, chromium as an additive to the ferric oxide has been explored widely for their improved catalytic activity due to the unique performance to the role of chromium in stabilizing the ferric oxide against sintering. To enhance the reduction performance of ferric oxide, the addition of other metal additives was considered. In this study we report the reduction behavior of the addition of chromium species into ferric oxides catalyst. The temperature programme reduction was performed to investigate the non-isothermal reduction behaviour of $\mathrm{Cr}$ doped ferric oxide by comparing to none doped species. Moreover, the kinetic studies were also carried out to calculate the activation energy of the reduction process using different heating rate.

\section{Chemicals and raw materials}

\section{Materials and Methods}

Iron (III) oxide (99\%) was obtained from Sigma Aldrich Chemical Company and chromium (III) nitrate from R\&M Chemicals. Gas mixture $\mathrm{CO} / \mathrm{N}_{2}(10 \% \mathrm{CO})$ was obtained from Linde.

\section{Catalyst preparation}

The $\mathrm{Cr}$ doped ferric oxide was prepared by impregnating $\mathrm{Fe}_{2} \mathrm{O}_{3}$ powder with aqueous solution containing chromium cation additives. The amount of chromium added was adjust to be 3 wt $\%$ in $\mathrm{Fe}_{2} \mathrm{O}_{3}$. The $\mathrm{Fe}_{2} \mathrm{O}_{3}$ powder was directly impregnated into $50 \mathrm{ml}$ distilled water corresponding metal cation additives in the above proportion and stirred vigorously for 2 hours at room temperature. The impregnated sample was dried at $110{ }^{\circ} \mathrm{C}$ overnight and subsequently calcined at $600{ }^{\circ} \mathrm{C}$ in the furnace for 3 hours. 


\section{Characterization studies}

Temperature programmed reduction (TPR) measurements was conducted using a Micromeritic Autochem 2920 Chemisorption Analyzer apparatus; a feed of $10 \% \mathrm{CO}$ in $\mathrm{N}_{2}$ at a flow rate of $20 \mathrm{~mL} \mathrm{~min}^{-1}$ (Standard Temperature and Pressure, STP) was used as reducing gas. An amount $50 \mathrm{mg}$ of samples were heated up to $900{ }^{\circ} \mathrm{C}$, at a rate of 10 ${ }^{\circ} \mathrm{C} \min ^{-1}$. For the kinetic study, different heating rate $\left(10,13,15{ }^{\circ} \mathrm{C} \min ^{-1}\right)$ were applied to the samples. The reduction kinetics of doped ferric oxides is an essential point that deserves investigation. There are numerous models in the literature for the estimation of the kinetic parameters and in this study Wimmers's method [11] was chosen and it describes the correlation between shifts in $\mathrm{T}_{\max }$ with the heating rate. In this method, the activation energy can be calculated from TPR data by using equation (5) below:

$$
\ln \left(\Psi / \mathrm{T}_{\max }\right)=-\mathrm{E}_{\mathrm{a}} / \mathrm{RT}_{\max }+\ln \left(\mathrm{AR} / \mathrm{E}_{\mathrm{a}}\right)+\mathrm{C}
$$

The activation energy is achieved from the shift of rate maximum temperature $\left(\mathrm{T}_{\max }\right)$ against the heating rate $(\Psi)$. If a straight line graph is obtained from the plot of $\ln \left(\Psi / T_{\max }\right)$ versus $1 /\left(T_{\max }\right)$, the slop is $E_{a} / R$ which $R$ is the gas constant. To investigate the role of $\mathrm{Cr}$ in the reduction behaviour of $\mathrm{Fe}_{2} \mathrm{O}_{3}$, the samples were collected and XRD patterns were measured. Samples were collected according to the TPR pattern when the reduction of $\mathrm{Cr}-\mathrm{Fe}_{2} \mathrm{O}_{3}$ is assumed to be finished at $700{ }^{\circ} \mathrm{C}$. Meanwhile, undoped $\mathrm{Fe}_{2} \mathrm{O}_{3}$ was also collected at $700{ }^{\circ} \mathrm{C}$ for the comparison purposes. The carbon monoxide consumption was monitored using a thermal conductivity detector (TCD). Phase characterization was carried out by X-ray diffraction (XRD) Bruker AXS D8 Advance type with X-ray radiation source of $\mathrm{Cu} \mathrm{K} \alpha(40 \mathrm{kV}, 40 \mathrm{~mA})$ to record the $2 \theta$ diffraction angle from $10-80$ degree at wavelength $(\lambda=0.154$ $\mathrm{nm})$. For identification purposes of crystalline phase composition, diffraction patterns obtained were matched with Joint Committee on Powder Diffraction Standards (JCPDS) files. Physical surface analysis (Brunauer-EmmettTeller, BET) of nitrogen adsorption at $77 \mathrm{~K}$ (liquid nitrogen) was conducted using a Micromeritics ASAP 2010 instrument to obtain the adsorption isotherm of each sample. The calcined sample of $\mathrm{Cr}-\mathrm{Fe}_{2} \mathrm{O}_{3}$ and $\mathrm{Fe}_{2} \mathrm{O}_{3}$ were degassed at $350{ }^{\circ} \mathrm{C}$ for $6 \mathrm{~h}$ before the BET surface area analyses were done. The Brunauer-Emmett-Teller (BET) surface area were calculated from the isotherms.

\section{Isotherm adsorption of $\mathbf{N}_{2}$}

\section{Results and Discussion}

The result indicates that the impregnation of $\mathrm{Fe}_{2} \mathrm{O}_{3}$ with chromium nitrate $\left(5.90 \mathrm{~m}^{2} / \mathrm{g}\right)$ shows the BET surface area was a little larger than undoped $\mathrm{Fe}_{2} \mathrm{O}_{3}\left(4.67 \mathrm{~m}^{2} / \mathrm{g}\right)$ manifesting that $\mathrm{Cr}$ could also prevent the aggregation of particles. Moreover, Hu et al. [11] mentioned that specific surface area was also an important factor as higher specific surface area usually results in more unsaturated surface coordination sites exposed to the gas which may result in the increasing of the reducibility performance of the ferric oxide in this study.

\section{Crystallinity effect by XRD}

Figure 1 shows the XRD patterns of $\mathrm{Cr}-\mathrm{Fe}_{2} \mathrm{O}_{3}$ and undoped $\mathrm{Fe}_{2} \mathrm{O}_{3}$ before reduction in $\mathrm{CO}$ in nitrogen (10\%, v/v). The XRD patterns obtained for both sample are identical to the $\mathrm{Fe}_{2} \mathrm{O}_{3}$ phase (ferric oxide, JCPDS 74-6271). The $2 \theta$ $\mathrm{Fe}_{2} \mathrm{O}_{3}$ main peaks reveal the presence of contribution at about 24.2, 33.2, 35.7, 40.9, 49.5, 53.5, 57.2, 62.4, 64.2, 72.4 and $75.7^{\circ}$. The diffraction peaks were shifted to higher $2 \theta$ positions which is mainly due to the interference of the $\mathrm{Cr}$ element changed the lattice constant of the $\mathrm{Fe}_{2} \mathrm{O}_{3}$. This can be attributed to the small atomic radius of $\mathrm{Fe}$ $(0.126 \mathrm{~nm})$ compared to those of $\mathrm{Cr}(0.128 \mathrm{~nm})$ that gave changed to the lattice parameters and lattice spacing. Furthermore, the diffraction peaks of freshly prepared $\mathrm{Cr}-\mathrm{Fe}_{2} \mathrm{O}_{3}$ showed an improvement in the crystallinity of the characteristic peaks of $\mathrm{Fe}_{2} \mathrm{O}_{3}$ when loaded with Cr. Furthermore, no additional peak observed in the XRD patterns showing that the chromium particles loaded on the ferric oxide were well dispersed.

From the observation in Figure 2, $\mathrm{Cr}-\mathrm{Fe}_{2} \mathrm{O}_{3}$ gives only metallic Fe diffraction peaks (iron, JCPDS 65-4899) at 700 ${ }^{0} \mathrm{C}$, while undoped $\mathrm{Fe}_{2} \mathrm{O}_{3}$ still consist of the remaining crystalline phases of $\mathrm{Fe}_{3} \mathrm{O}_{4}(3,1,1), \mathrm{Fe}_{3} \mathrm{O}_{4}(4,4,0)$ (magnetite, JCPDS 71-6336) and crystallite phases of $\mathrm{FeO}(1,1,1)$ and $\mathrm{FeO}(2,2,0)$ (wustite, JCPDS 80-0686). $\mathrm{Fe}_{2} \mathrm{O}_{3}$ showed a complete reduction to metallic $\mathrm{Fe}$ when the reduction temperature reached $900{ }^{\circ} \mathrm{C}$. To further investigate the mechanism involved in the reduction process of $\mathrm{Cr}-\mathrm{Fe}_{2} \mathrm{O}_{3}$ and undoped $\mathrm{Fe}_{2} \mathrm{O}_{3}$, samples were collected at various temperatures $\left(400,500,600\right.$ and $700{ }^{\circ} \mathrm{C}$ ) and detailed characterization using XRD were shown in Figure 3 and Figure 4, respectively. At temperature $400{ }^{\circ} \mathrm{C}$ and $500{ }^{\circ} \mathrm{C}$ the XRD patterns show strong diffraction peaks of 


\section{Tengku Shafazila et al: INFLUENCE OF CHROMIUM ON THE REDUCTION BEHAVIOR OF FERRIC OXIDE BY USING CARBON MONOXIDE: TEMPERATURE PROGRAMMED REDUCTION AND KINETIC STUDIES}

magnetite and a growth of metallic iron phases. By increasing the reduction temperature to $600{ }^{\circ} \mathrm{C}$, undoped $\mathrm{Fe}_{2} \mathrm{O}_{3}$ started to display a formation of metastable $\mathrm{FeO}$ with crystallite phases of $\mathrm{FeO}(1,1,1),(2,0,0),(2,2,0),(3,1,1)$ and $(2,2,2)$ (wustite, JCPDS 80-0686). The reduction of $\mathrm{Fe}_{3} \mathrm{O}_{4}$ to $\mathrm{FeO}$ proceeded at higher temperature $>570{ }^{0} \mathrm{C}$ while $\mathrm{FeO}$ was also reduced to $\mathrm{Fe}$, simultaneously (Fig.4). For $\mathrm{Cr}-\mathrm{Fe}_{2} \mathrm{O}_{3}, \mathrm{FeO}$ was not detected in the XRD patterns for the whole reduction process as the addition of chromium inhibits $\mathrm{FeO}$ phases to occur. This indicated that the formation of metastable $\mathrm{FeO}$ phase was not only affected by the reduction temperature but also depended on the nature of the sample itself, which in this case the involvement of chromium element in the structure of ferric oxide enhance it reducibility.

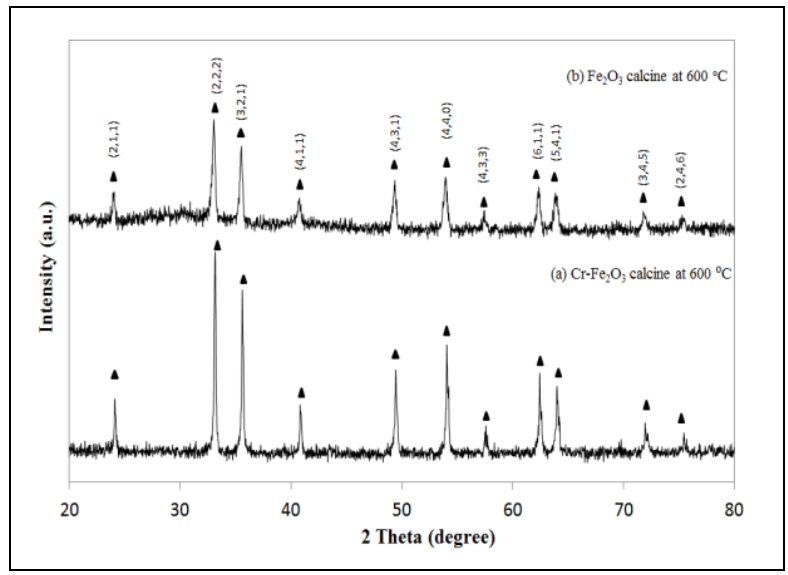

Figure 1. XRD diffractogram of (a) $\mathrm{Cr}-\mathrm{Fe}_{2} \mathrm{O}_{3}$ calcined at $600{ }^{\circ} \mathrm{C}$, and (b) fresh $\mathrm{Fe}_{2} \mathrm{O}_{3}$ calcined at $600{ }^{\circ} \mathrm{C}$. $(\Delta) \mathrm{Fe}_{2} \mathrm{O}_{3}$

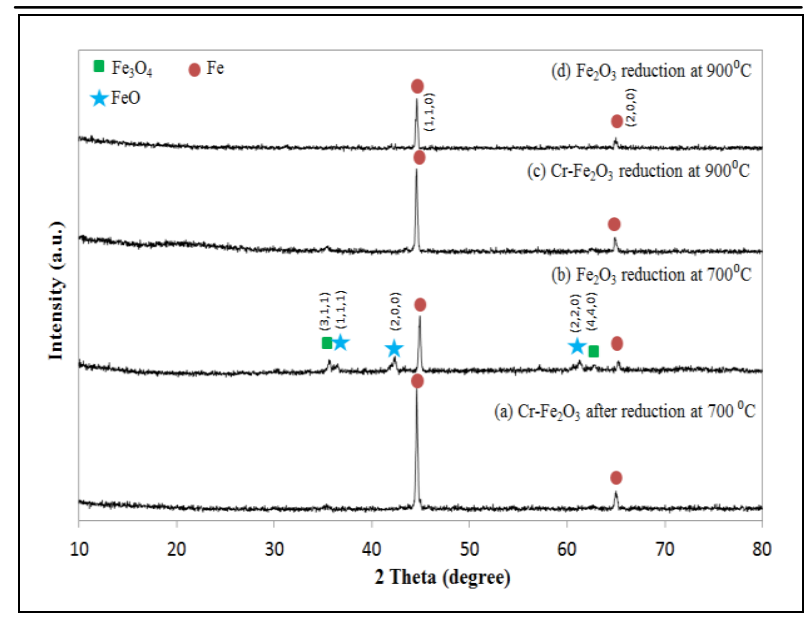

Figure 2. XRD diffractogram of (a) $\mathrm{Cr}-\mathrm{Fe}_{2} \mathrm{O}_{3}$ and (b) $\mathrm{Fe}_{2} \mathrm{O}_{3}$ after reduction by $\mathrm{CO}$ at $700{ }^{\circ}$, (c) $\mathrm{Cr}-\mathrm{Fe}_{2} \mathrm{O}_{3}$ and (d) $\mathrm{Fe}_{2} \mathrm{O}_{3}$ after reduction by $\mathrm{CO}$ at $900{ }^{\circ} \mathrm{C}$. (口) $\mathrm{Fe} 3 \mathrm{O} 4$, (* ) $\mathrm{FeO}$ and (•) metallic $\mathrm{Fe}$ 


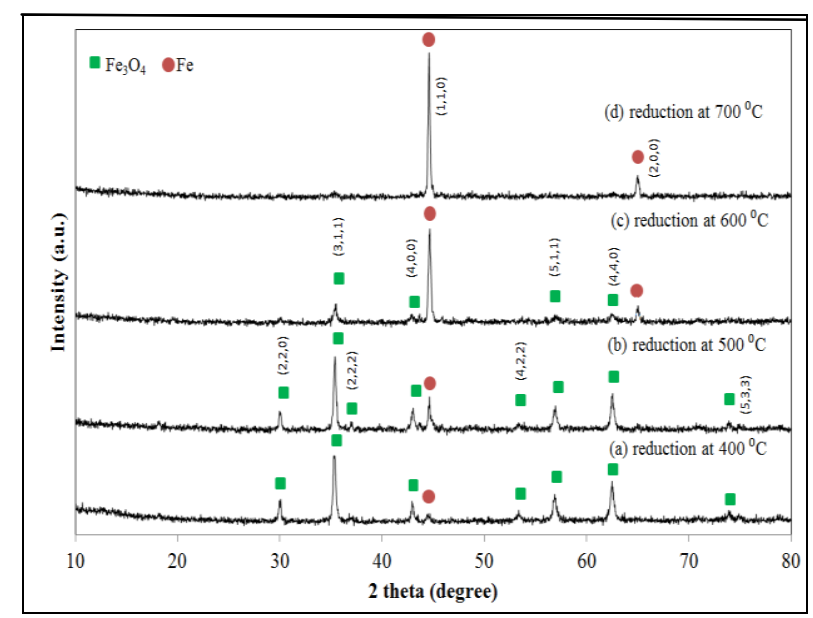

Figure 3. XRD diffractogram of $\mathrm{Cr}-\mathrm{Fe}_{2} \mathrm{O}_{3}$ after reduction by $\mathrm{CO}$ at $400{ }^{\circ} \mathrm{C}, 500{ }^{\circ} \mathrm{C}, 600{ }^{\circ} \mathrm{C}, 700{ }^{\circ} \mathrm{C}$. ( $\square) \mathrm{Fe}_{3} \mathrm{O}_{4}$ and $(\bullet)$ metallic $\mathrm{Fe}$

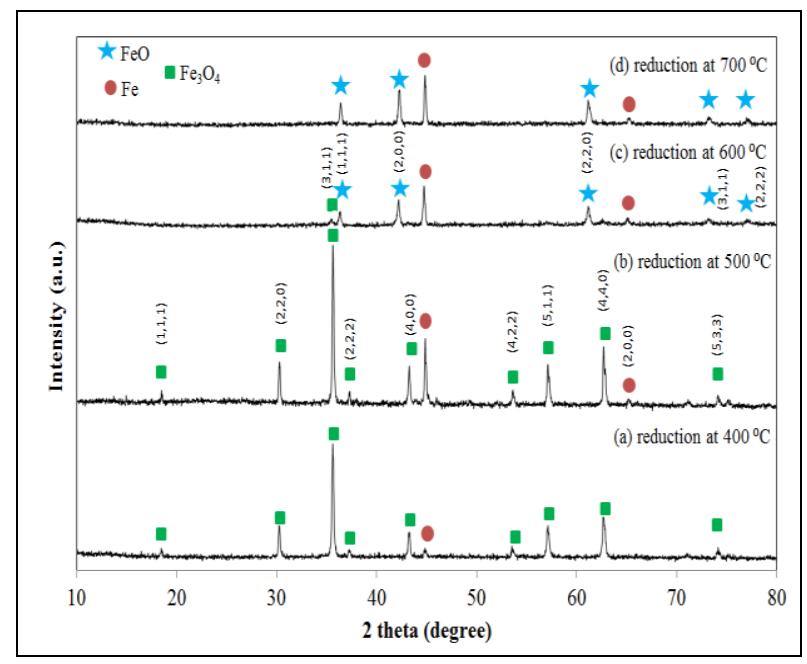

Figure 4. XRD diffractogram of $\mathrm{Fe}_{2} \mathrm{O}_{3}$ after reduction by $\mathrm{CO}$ at $400{ }^{\circ} \mathrm{C}, 500{ }^{\circ} \mathrm{C}, 600{ }^{\circ} \mathrm{C}, 700{ }^{\circ} \mathrm{C}$.

( $) \mathrm{Fe}_{3} \mathrm{O}_{4},(\star) \mathrm{FeO}$ and (o metallic $\mathrm{Fe}$

\section{Chemical properties by TPR analysis}

The TPR patterns for non-isothermal reduction of $\mathrm{Cr}-\mathrm{Fe}_{2} \mathrm{O}_{3}$ and undoped $\mathrm{Fe}_{2} \mathrm{O}_{3}$ by $\mathrm{CO}$ in nitrogen $(10 \%$, v/v) is shown in Figure 5. The TPR profiles of undoped $\mathrm{Fe}_{2} \mathrm{O}_{3}$ represented 3 reduction events (denoted I, II and III) which event I represent to peak displayed at lower temperature exhibited the reduction of $\mathrm{Fe}_{2} \mathrm{O}_{3} \rightarrow \mathrm{Fe}_{3} \mathrm{O}_{4}$. Meanwhile, the second peak (event II) was related to the reduction of $\mathrm{Fe}_{3} \mathrm{O}_{4} \rightarrow \mathrm{FeO}$ and the last peak (event III) was attributed to the reduction of $\mathrm{FeO}$ to metallic $\mathrm{Fe}$. Three reduction events of $\mathrm{Fe}_{2} \mathrm{O}_{3}$ reflected by 3 peaks around $361{ }^{\circ} \mathrm{C}$ (I), $509{ }^{\circ} \mathrm{C}$ (II) and $807{ }^{\circ} \mathrm{C}$ (III) as display in Figure 5., showing three-steps reduction route of $\mathrm{Fe}_{2} \mathrm{O}_{3}$ to $\mathrm{Fe}$ through $\mathrm{Fe}_{3} \mathrm{O}_{4}$ and $\mathrm{FeO}$ as an intermediate and for $\mathrm{Cr}-\mathrm{Fe}_{2} \mathrm{O}_{3}$, the temperature for the peak obtained for event $\mathrm{I}$ is $353{ }^{\circ} \mathrm{C}$ and for higher temperature, the peaks were observed overlaping to each other with a shoulder at $507{ }^{\circ} \mathrm{C}$ and a peak at $591{ }^{\circ} \mathrm{C}$. The higher temperature shoulder of $\mathrm{Cr}-\mathrm{Fe}_{2} \mathrm{O}_{3}$ may refer to the $\mathrm{Fe}_{3} \mathrm{O}_{4}$ to complete the reduction process by forming a better crystallite of $\mathrm{Fe}_{3} \mathrm{O}_{4}$ as indicated in the XRD results and another peak may refer to further reduction of $\mathrm{Fe}_{3} \mathrm{O}_{4}$ to metallic $\mathrm{Fe}$. The absence of $\mathrm{FeO}$ throughout the reduction process of $\mathrm{Cr}-\mathrm{Fe}_{2} \mathrm{O}_{3}$ attributed to two-steps of 


\section{Tengku Shafazila et al: INFLUENCE OF CHROMIUM ON THE REDUCTION BEHAVIOR OF FERRIC OXIDE BY USING CARBON MONOXIDE: TEMPERATURE PROGRAMMED REDUCTION AND KINETIC STUDIES}

reduction $\left(\mathrm{Fe}_{2} \mathrm{O}_{3} \rightarrow \mathrm{Fe}_{3} \mathrm{O}_{4} \rightarrow\right.$ metallic $\left.\mathrm{Fe}\right)$. Furthermore, the addition of $\mathrm{Cr}$ to ferric oxide enhance the reducibility of the ferric oxide to metallic $\mathrm{Fe}$ by shifted the peaks to lower temperature and completed at $700{ }^{\circ} \mathrm{C}$ which was lower than undoped $\mathrm{Fe}_{2} \mathrm{O}_{3}\left(900^{\circ} \mathrm{C}\right)$ as also confirmed by XRD analysis.

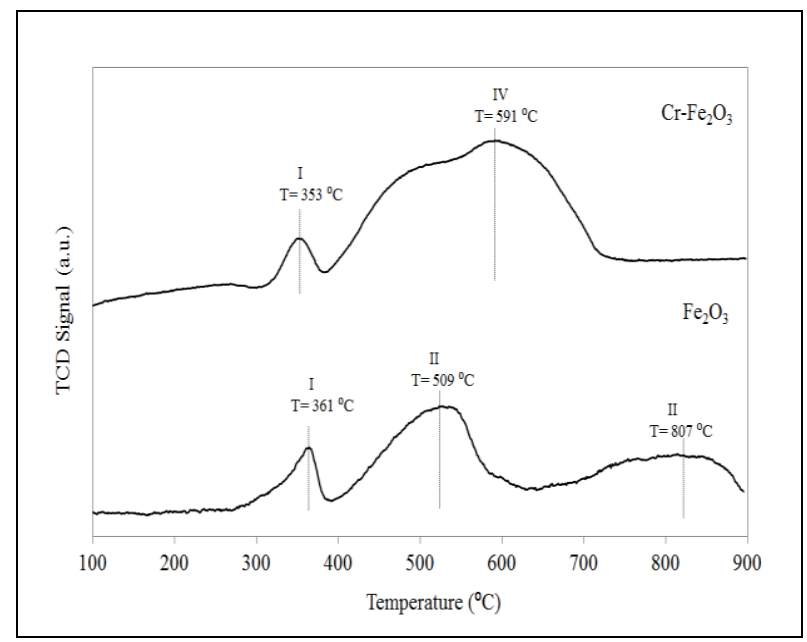

Figure 5. TPR profile of $\mathrm{Fe}_{2} \mathrm{O}_{3}$ and $\mathrm{Cr}-\mathrm{Fe}_{2} \mathrm{O}_{3}$

\section{Activation energy (Ea) effect}

To evaluate the activation energy of $\mathrm{Cr}-\mathrm{Fe}_{2} \mathrm{O}_{3}$ and undoped $\mathrm{Fe}_{2} \mathrm{O}_{3}$ a TPR measurement with various heating rates $\left(10,13\right.$ and $\left.15^{\circ} \mathrm{C} / \mathrm{min}\right)$ were carried out. The results showed that by increasing the heating rate, the peaks showing a maximal temperature were shifted to higher temperature as shown in Figure 6.
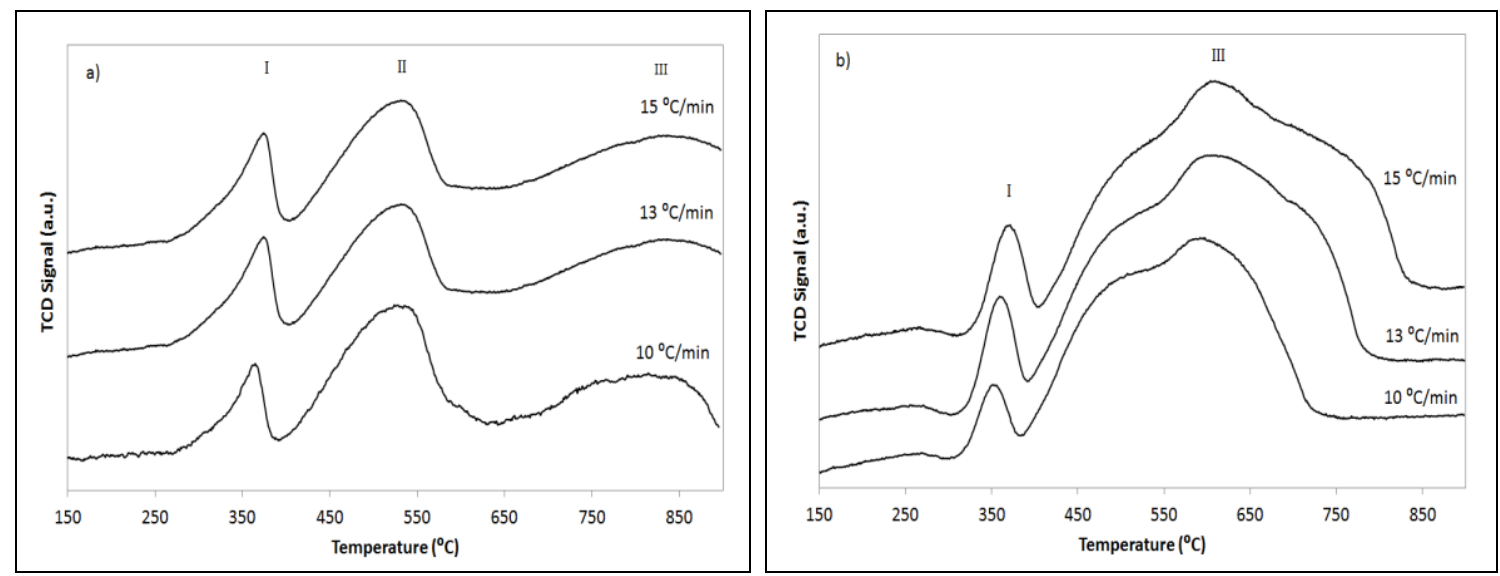

Figure 6. TPR profiles of (a) $\mathrm{Fe}_{2} \mathrm{O}_{3}$ and (b) $\mathrm{Cr}-\mathrm{Fe}_{2} \mathrm{O}_{3}$ reduction by carbon monoxide with heating ramp of $10{ }^{\circ} \mathrm{C} / \mathrm{min}, 13{ }^{\circ} \mathrm{C} / \mathrm{min}$ and $15{ }^{\circ} \mathrm{C} / \mathrm{min}$

To describe the process, we considered that during the TPR analysis, 3 reduction steps involve for undoped $\mathrm{Fe}_{2} \mathrm{O}_{3}$ and 2 reduction steps for $\mathrm{Cr}-\mathrm{Fe}_{2} \mathrm{O}_{3}$. The processes were described below with the rate constant of $\mathrm{K}_{\mathrm{I}}, \mathrm{K}_{\mathrm{II}}, \mathrm{K}_{\mathrm{III}}$ and $\mathrm{K}_{\mathrm{IV}}$. 


$$
\begin{aligned}
& \mathrm{Fe}_{2} \mathrm{O}_{3}: \quad \mathrm{Fe}_{2} \mathrm{O}_{3} \stackrel{\mathrm{K}_{\mathrm{I}}}{\rightarrow} \mathrm{Fe}_{3} \mathrm{O}_{4} \stackrel{\mathrm{K}_{\text {II }}}{\rightarrow} \mathrm{FeO} \stackrel{\mathrm{K}_{\text {III }}}{\rightarrow} \mathrm{Fe} \\
& \mathrm{Cr}-\mathrm{Fe}_{2} \mathrm{O}_{3}: \quad \mathrm{Fe}_{2} \mathrm{O}_{3} \stackrel{\mathrm{K}_{\mathrm{I}}}{\rightarrow} \mathrm{Fe}_{3} \mathrm{O}_{4} \stackrel{\mathrm{K}_{\mathrm{IV}}}{\rightarrow} \mathrm{Fe}
\end{aligned}
$$

The $\mathrm{E}_{\mathrm{a}}$ for undoped $\mathrm{Fe}_{2} \mathrm{O}_{3}$ and $\mathrm{Cr}-\mathrm{Fe}_{2} \mathrm{O}_{3}$ by referring to their transition phase were shown in Table 1. The results suggest that by adding $\mathrm{Cr}$ metal into ferric oxide, the Ea value decrease by $12.39 \%$ for the reduction step of $\mathrm{Fe}_{2} \mathrm{O}_{3}$ $\rightarrow \mathrm{Fe}_{3} \mathrm{O}_{4}$ that lower the reduction temperature. This also in agreement with previous work by Ryu et. al. (2008) [12] with addition of metal additive in their case is $\mathrm{Ru}$ metal, played an important role on lowering the reduction temperature which also due to a decrease of activation energy according to $\mathrm{Fe}_{2} \mathrm{O}_{3} \rightarrow \mathrm{Fe}_{3} \mathrm{O}_{4}$ course in $\mathrm{H}_{2}$ reducing atmosphere. Nevertheless, Ea value regarding to other transition phases could not be compared since both samples involved a different mechanism in the reduction process. Moreover, $\mathrm{Cr}-\mathrm{Fe}_{2} \mathrm{O}_{3}$ which gives two reduction steps with transition phase of $\mathrm{Fe}_{2} \mathrm{O}_{3} \rightarrow \mathrm{Fe}_{3} \mathrm{O}_{4}$ display an $\mathrm{E}_{\mathrm{a}}$ value of $123.7 \mathrm{~kJ} \mathrm{~mol}^{-1}$ and $\mathrm{Fe}_{3} \mathrm{O}_{4} \rightarrow \mathrm{Fe}$ give a value of $89.0 \mathrm{~kJ}$ $\mathrm{mol}^{-1}$. For undoped $\mathrm{Fe}_{2} \mathrm{O}_{3}$ three values of Ea were calculated, first transition of $\mathrm{Fe}_{2} \mathrm{O}_{3} \rightarrow \mathrm{Fe}_{3} \mathrm{O}_{4}$ give a value of 141.2 $\mathrm{kJ} \mathrm{mol}^{-1}$, second and third transition of $\mathrm{Fe}_{3} \mathrm{O}_{4} \rightarrow \mathrm{FeO}$ and $\mathrm{FeO} \rightarrow \mathrm{Fe}$ give Ea value of $82.5 \mathrm{~kJ} \mathrm{~mol}^{-1}$ and $100.3 \mathrm{~kJ}$ mol $^{-1}$, respectively.

\begin{tabular}{|c|c|c|c|c|}
\hline Sample & $\begin{array}{c}\mathrm{E}_{\mathrm{a}}^{\mathrm{I}}\left(\mathrm{kJ} \mathrm{mol}^{-1}\right) \\
\mathrm{Fe}_{2} \mathrm{O}_{3} \rightarrow \mathrm{Fe}_{3} \mathrm{O}_{4}\end{array}$ & $\begin{array}{c}\mathrm{E}_{\mathrm{a}}^{\mathrm{II}}\left(\mathrm{kJ} \mathrm{mol}^{-1}\right) \\
\mathrm{Fe}_{3} \mathrm{O}_{4} \rightarrow \mathrm{FeO}\end{array}$ & $\begin{array}{c}\mathrm{E}_{\mathrm{a}}^{\mathrm{III}}\left(\mathrm{kJ} \mathrm{mol}^{-1}\right) \\
\mathrm{FeO} \rightarrow \mathrm{Fe}\end{array}$ & $\begin{array}{c}\mathrm{E}_{\mathrm{a}}^{\mathrm{IV}}\left(\mathrm{kJ} \mathrm{mol}^{-1}\right) \\
\mathrm{Fe}_{3} \mathrm{O}_{4} \rightarrow \mathrm{Fe}\end{array}$ \\
\hline $\mathrm{Cr}-\mathrm{Fe}_{2} \mathrm{O}_{3}$ & 123.7 & n.d. & n.d. & 89.0 \\
\hline $\mathrm{Fe}_{2} \mathrm{O}_{3}$ & 141.2 & 82.5 & 100.3 & n.d. \\
\hline
\end{tabular}

Table 1. The $\mathrm{E}_{\mathrm{a}}$ of $\mathrm{Fe}_{2} \mathrm{O}_{3}$ and $\mathrm{Cr}-\mathrm{Fe}_{2} \mathrm{O}_{3}$ according to the transition phase

Note: n.d. $=$ not detected.

Referring to Table 1, it has been seen that the activation energy for reduction steps of $\mathrm{Fe}_{2} \mathrm{O}_{3} \rightarrow \mathrm{Fe}_{3} \mathrm{O}_{4}$ is higher compare to the other transition phases. The values were unpredicted but somehow was similar to the activation energy obtained by Munteanu et al. [13] for reduction of fresh $\alpha-\mathrm{Fe}_{2} \mathrm{O}_{3}$ by $10 \%$ hydrogen in argon with the reduction steps of $\mathrm{Fe}_{2} \mathrm{O}_{3} \rightarrow \mathrm{Fe}_{3} \mathrm{O}_{4}$ give $139.2 \mathrm{~kJ} \mathrm{~mol}^{-1}$ and $\mathrm{Fe}_{3} \mathrm{O}_{4} \rightarrow \mathrm{FeO}$ and $\mathrm{FeO} \rightarrow \mathrm{Fe}$ were 77.3 and $85.7 \mathrm{~kJ}$ $\mathrm{mol}^{-1}$, respectively [13].

\section{Conclusion}

The kinetics and reduction behaviour of chromium doped $\mathrm{Fe}_{2} \mathrm{O}_{3}$ and undoped $\mathrm{Fe}_{2} \mathrm{O}_{3}$ were investigated and compared using TPR technique and characterized by XRD and BET. The data obtained from XRD evidenced the presence of well dispersed chromium particles loaded on the ferric oxide and promotes better crystallinity of the $\mathrm{Fe}_{2} \mathrm{O}_{3}$ leads to the effect on enhancing the reduction process by lowering the reduction temperature of $\mathrm{Fe}_{2} \mathrm{O}_{3}$ to metallic Fe which has been completed at $700{ }^{\circ} \mathrm{C}$ compare to undoped $\mathrm{Fe}_{2} \mathrm{O}_{3}\left(900{ }^{\circ} \mathrm{C}\right)$. The reducing path of ferric oxide was found to be dependent on the doped element as $\mathrm{Cr}$ doped ferric oxide favours complete reduction to metallic iron without formation of intermediate $\mathrm{FeO}$. Thus, addition of chromium element give a two-steps reduction $\left(\mathrm{Fe}_{2} \mathrm{O}_{3} \rightarrow \mathrm{Fe}_{3} \mathrm{O}_{4} \rightarrow\right.$ metallic $\left.\mathrm{Fe}\right)$ and undoped ferric oxide preferentially reduced through wüstite formation with three-steps reduction $\left(\mathrm{Fe}_{2} \mathrm{O}_{3} \rightarrow \mathrm{Fe}_{3} \mathrm{O}_{4} \rightarrow \mathrm{FeO} \rightarrow\right.$ metallic Fe). Furthermore, better reducibility of $\mathrm{Cr}-\mathrm{Fe}_{2} \mathrm{O}_{3}$ is also due to the higher in surface area and the decrease of the activation energy regarding to transition phases of $\mathrm{Fe}_{2} \mathrm{O}_{3} \rightarrow \mathrm{Fe}_{3} \mathrm{O}_{4}$ during the reduction process by carbon monoxide compare to undoped one.

\section{Acknowledgement}

The author wish to thank Ministry of Higher Education (MOHE) for funding this project under research grant number BKBP-FST-K003323-2014, FRGS/2/2013/TK06/UKM/02/3, ETP-2013-066, TD-2014-024 \& Centre of Research and Innovation Management CRIM-UKM for instruments facilities. 


\section{References}

1. Pineau, A., Kanari, N. and Gaballah, I. (2007). Kinetics of reduction of iron oxides by $\mathrm{H}_{2}$, Thermochimica Acta, 456(2): $75-88$.

2. Li, K., Haneda, M., Gu, Z., Wang, H. and Ozawa, M. (2013). Modification of $\mathrm{CeO}_{2}$ on the redox property of $\mathrm{Fe}_{2} \mathrm{O}_{3}$. Materials Letters, 93: $129-132$.

3. Monazam, E. R., Breault, R. W. and Siriwardane, R. (2014). Reduction of hematite $\left(\mathrm{Fe}_{2} \mathrm{O}_{3}\right)$ to wüstite (FeO) by carbon monoxide (CO) for chemical looping combustion, Chemical Engineering Journal, 242: 204 - 210.

4. Pickles, C. A. (2008). Thermodynamic analysis of the separation of zinc and lead from electric arc furnace dust by selective reduction with metallic iron. Separation and Purification Technology, 59: 115 - 128.

5. Longbottom, R. and Kolbeinsen, L. (2008). Iron ore reduction with $\mathrm{CO}$ and $\mathrm{H}_{2}$ gas mixtures - thermodynamic and kinetic modelling. Proceedings of $4^{\text {th }}$ Ulcos Seminar, October: $1-13$.

6. Colombo, U., Gazzarrini, F. and Lanzavecchia, G. (1967). Mechanisms of iron oxides reduction at temperatures below $400{ }^{\circ} \mathrm{C}$. Materials Science Engineering, 2(3):125 - 135.

7. Jozwiak, W. K., Kaczmarek, E., Maniecki, T. P., Ignaczak, W. and Maniukiewicz, W. (2007). Reduction behavior of iron oxides in hydrogen and carbon monoxide atmospheres. Applied Catalysis A: General, 326(1): $17-27$.

8. Leith, I. R. and Howden, M. G. (1988). Temperature-programmed reduction of mixed iron-manganese oxide catalysts in hydrogen and carbon monoxide. Applied Catalysis, 37:75 - 92.

9. Khan A. and Smirniotis, P. G. (2008). Relationship between temperature-programmed reduction profile and activity of modified ferrite-based catalysts for WGS reaction. Journal of Molecular Catalysis A: Chemical 280: $43-51$.

10. Mondal, K., Lorethova, H., Hippo, E., Wiltowski, T. and Lalvani, S. B. (2004). Reduction of iron oxide in carbon monoxide atmosphere - reaction controlled kinetics. Fuel Processing Technology, 86(1): 33 - 47.

11. $\mathrm{Hu}, \mathrm{C}$., Gao, Z. and Yang, X. (2007). Facile synthesis of single crystalline $\alpha-\mathrm{Fe}_{2} \mathrm{O}_{3}$ ellipsoidal nanoparticles and its catalytic performance for removal of carbon monoxide, Materials Chemistry and Physics, 104 (2-3): 429 433.

12. Ryu, J. C., Lee, D. H., Kang, K. S., Park, C. S., Kim, J. W. and Kim, Y. H. (2008). Effect of additives on redox behavior of iron oxide for chemical hydrogen storage, Journal of Industrial and Engineering Chemistry, 14(2): $252-260$.

13. Munteanu, G., Illieve, L. and Andreeva, D. (1997). Kinetic parameters obtained from TPR data for ol- $\mathrm{Fe}_{2} \mathrm{O}_{3}$ and $\mathrm{Au} / \mathrm{o} \sim-\mathrm{Fe}_{2} \mathrm{O}_{3}$ systems, Thermochimica Acta, 291:171 - 177. 